\title{
Letter from the Editors
}

Since the establishment of IGEER in 1974, historians at Leiden University have concentrated their research on the role of Western European institutions in the globalization of human societies. Having played a pioneering role in the field, we are glad to conclude that over the past ten years Leiden's bilateral research programs have been transformed into multilateral cooperation programs and summer schools under the aegis of the Erasmus program and the European Science Foundation. We trust that this globalization of research and teaching will further strengthen the multidisciplinary and comparative approach of this journal.

Last April, the founding meeting of the American Forum for the Study of European Expansion and Global Reactions was held at Brown University, Providence R.I. This highly successful symposium was attended by three scholars from academic institutions all over the US. At the final session it was agreed that Itinerario will also serve as 'inhouse journal' to the newly established American chapter. Michael Adas and Patricia Seed, members of the American Forum committee, are hereby welcomed to our editorial board. They will coordinate the selection of articles for this journal submitted by members of the American Forum. As indicated elsewhere in this volume members of the American Forum may subscribe to Itinerario through the kind services of the John Carter Brown library of Brown University. In the autumn issue we hope to publish a detailed report of the meeting at Brown University.

The Leiden History Department has initiated a lecture series for outstanding students, entitled Crayenborgh Master Course. Lectures from this series that we feel might interest the readers of Itinerario will be published in this journal. The first to be published is a presentation by Liah Greenfeld with reflections on her recent book.

Since the last issue, Itinerario has undergone a changing of the guards. The present editors would like to thank Piet Emmer and Dirk Kolff for their inspiring direction of this journal over the past ten years.

Leonard Blussé \& Hans Vogel 